\section{School Privatisation: A Review and Critique}

\section{JOHN BARRINGTON}

\section{Abstract:}

While the marketisation of education has been the subject of considerable attention and often heated debate within the policy arena in New Zealand (Lauder et al., 1994) the issue of school privatisation has received relatively little attention. Undoubtedly at least part of the reason for this is that the proportion of pupils enrolled in private schools (currently 4\%) remains small by international standards. However recent policy developments and advocacy of greater school privatisation by a variety of organisations foreshadow considerable pressures for further expansion of the private sector. A description and analysis of this trend and responses to it form the main focus of the paper.

$\mathrm{P}$

rivatisation of schools is a trend the National government supports. In its election manifesto National declared that "The private school sector in New Zealand is too small for the good health of our education system." It would progressively increase support for private schools to "ensure private education is a realistic alternative for parents" (National Party Policy on Education, 1990). The year 1995 saw increased government resourcing of private schools. The Budget in June announced that support for the salaries of teachers in private schools will increase from \$14 million in 1995 to \$26 million in 1997/8. By 1998 the state will subsidise private schools at $40 \%$ of the state per-pupil rate for years $11-13$ and at $25 \%$ for all other years. A three-year pilot scheme called Targeted Individual Entitlement (TIE) will provide an additional \$2.5 million over three years to enable 160 students from low income families to enrol in private schools (Budget, 1995). In November 1995 the Minister of Education made his most forthright statement to date advocating direct government funding of parents to enable them to enrol their children in a school of their choice (Lockwood Smith, November 4).

\section{John Barrington}

\section{The Targeted Individual Entitlement Scheme}

Differences of opinion between Treasury and the Ministry of Education over this scheme deserve some separate comment, not least because of the insights provided into the kinds of policy disagreements that can occur between departments and ministers during the policy formation process. Treasury and Ministry of Education papers obtained by the writer under the Official Information Act demonstrate that Treasury believed the TIE scheme deserved testing because it might be an effective way to " $(1)$ improve the achievement levels of such students by enhancing their education choices; (2) increase incentives to state schools to improve their performance in educating children from lower socio-economic backgrounds" (Treasury, 1995, 31 March). However when it came to the details of the scheme, Treasury wanted to explore some quite different options from those advocated by the Ministry of Education in the following areas:

\section{Eligibility criteria}

In May 1995, Treasury expressed disagreement with the Minister of Education's initial proposal that a combined maximum parental income of $\$ 17,000$ be the eligibility criterion for the scheme (Treasury Briefing Paper, 1995). Treasury regarded long-term beneficiary status as preferable to a given level of taxable income, arguing it was likely to cover students who had been exposed to a relatively sustained period of low parental income, were in the care of a solo parent, had parents with "low labour market attachment", and a mother who had low educational achievement. On these grounds Treasury therefore argued that eligibility be confined to the approximately 89,000 students whose primary caregiver had been receiving an income support benefit for two years or longer.

The proposed draft scheme was then returned to officials for further work and discussion. By June 1995 the Minister of Education's own position on eligibility had changed, at least in part as a response to the expression by Cabinet members of a preference for including working families in the target group. He now recommended that the maximum taxable income level should be set at $\$ 25,000$. At this level, families with two parents both working in low paying jobs would qualify for the scheme and many more pupils (approximately 170,000) would be eligible. When final details of the scheme were publicly announced it was the Minister's preferred income level of $\$ 25,000$ which had prevailed with Cabinet. 


\section{Selection}

The Minister of Education proposed that student selection should be carried out by each of the private schools students had applied to. However Treasury regarded this as "inappropriate", because it believed schools would "cream off" candidates they regarded as most desirable either on academic or social grounds. Treasury favoured centralised selection by ballot, arguing this would produce a more diverse group of students and consequently a more "robust evaluation" of the scheme's overall effectiveness.

\section{Administration}

The Minister of Education proposed awarding the contract for administering the pilot scheme to the Independent Schools Council. However Treasury again demurred, regarding this as involving a potential conflict of interest because the Council represented a significant number of private schools. It suggested that a different agency such as the Special Education Service might be preferable.

\section{Value of the entitlement}

According to the Minister, the value of the entitlement needed to be $110 \%$ of the long-run average cost of state schooling, in order to ensure that private schools were affordable for accepted students. But Treasury argued that the value should be equivalent to the resources students would attract in a state school, otherwise it would be impossible to determine the effectiveness of private schooling for students in the pilot study in comparison with that of their state schooling peers.

\section{Duration of the grant}

The Minister wanted each grant to be made available for a period of six years, with eligibility retested after three years. However Treasury's view was that any mid-point retesting requirement might provide an incentive, "albeit slight, to remain on a benefit rather than move into paid employment". Treasury therefore recommended that grantees should be able to complete their schooling on the grant with no retesting of eligibility.

\section{Summary}

In the final outcome, the Minister's view prevailed with each of the components of the scheme discussed above, i.e., selection, administration (to be done jointly by the Ministry and the Independent Schools Council), value and duration.

\section{Further details}

Primary schools accepting students receive $\$ 3,685$ per student, and their families receive a further $\$ 900$ for transport and uniform costs; secondary schools receive $\$ 5,995$ and $\$ 1,100$ goes to the family. (Office of the Minister of Education, Papers on the TIE Scheme, 1995). The administrators of the scheme, the Independent Schools Council and the Ministry of Education, will make regular checks on student progress and well-being. Towards the end of the first three-year period, the scheme's success will be evaluated on various measures, including demand for places, student progress and parental satisfaction.

Dr Lockwood Smith said TIE was not based on any assumptions about the relative quality of education at state or independent schools but was "a programme to provide greater equity in terms of school choice .... It will mean families on benefits living in South Auckland will be able to exercise the same choices as Doug Myers and Sir Michael Fay" (Office of the Minister of Education, News Release, 18 July 1995). Subsequent official explanation about the scheme declared that its aim was to

... lift the level of educational achievement among the target group of students. By giving the power of choice to families whose options are currently limited, TIE makes it more likely that these families will get the kind of education that they want for their children, and this in turn is likely to contribute to a higher achievement rate among these children. (Office of the Minister of Education, Papers on the TIE scheme, 1995)

Guidelines to parents, schools and administrators on the TIE scheme pointed out that while there was no asset test applying, students from families with considerable assets but low incomes ("asset rich and income poor") should be discouraged from applying. Schools were informed of the government's concern to see that students whose families are over-represented in the low income category, in particular Maori and Pacific Island students, had the opportunity to participate. In any year where there are more than 160 places offered, priority will be given to: (a) schools that are most accessible to the largest number of low income families; and (b) ensuring a reasonable geographic spread. A balance will also be sought between single sex and co-ed places to ensure that both girls and boys have similar opportunities for participation. Schools are advised to bear in mind that "TIE is not simply a scholarship for the academically able; the intention is to 'open more 
doors' for all students whose present options are limited". A key assumption underpinning the scheme is stated to be that students

regardless of their academic ability, are more likely to achieve greater success in school if both they and their parents actively "buy into" the school and its programme ... the selection process will therefore acknowledge that the very act of applying for a place signals a readiness by the student and his or her family to capitalise on opportunities that are offered. In selecting students, schools are encouraged to give weight to the degree of commitment of both student and family. (Office of the Minister of Education, Papers on the TIE scheme, 1995)

Guidelines provide additional official perspectives on the scheme. Administrators are advised that for families on moderate to high incomes the ability to select a school most likely to deliver the kind of education they want for their children is "relatively unrestrained ... they can afford to transport their children across town, or move closer to the school of their choice, or pay fees to gain access to private schools". The availability of these options, it is claimed, makes it more likely that such families can find a school that matches their expectations and aspirations for their children. This situation is then contrasted with that facing families on low incomes who do not have this choice, whose options are limited because of cost, and for whom there are currently few alternatives when they "want something more for their children than the local school" (Office of the Minister of Education, Papers on the TIE scheme, 1995).

\section{Response}

The developments described brought a mixed reaction. The Executive Director of the Independent Schools Council, Ms Jan Kerr, was enthusiastic about the TIE scheme and would like the government to fund more places in private schools (Kerr, 26 October 1995). However both teacher unions were critical. The National President of the New Zealand Educational Institute (NZEI Te Riu Roa), Helen Duncan, claimed spending \$2.5 million on "a pilot scheme for voucher education is a waste of money" (Duncan, 1995). The National Secretary, Ros Noonan, suggested Auckland parents concerned about teacher shortages should convince the Minister to abandon his pilot voucher scheme for sending low income children to private schools (Noonan, 1995). Ms Noonan estimated the scheme would cost almost $\$ 240,000$ more than if the 160 students involved remained in the state system in 1996, and the money would be better used for incentives to get teachers into state schools currently experiencing staff shortages. She described TIE as a "back door method" of privatising schools and claimed that, "allowing a handful of poor kids to attend rich schools is not the answer to giving all children a good education".

The new policy inevitably entered the party political domain. Labour said it was determined to stop both the TIE scheme and the boost to private school subsidies, bringing the reaction from Jan Kerr that its views on education were "locked in a philosophical time warp" (Kerr, September 19, 1995). Strong criticism of the TIE scheme came from the National member for Tasman, Nick Smith, who described it as a "shadow of ACT's ambitious proposal for a nationwide voucher system" (Smith, 1995). The danger of such a scheme, as he saw it, was that the education system would revert to the

class and wealth based systems that characterised pre-WW1 Europe ... It starts to look more like a Victorian approach to welfarism than a bold new educational initiative ... I can think of many far more useful ways in which to invest $\$ 2.5$ million in education ... Lockwood is putting his toe in the water to test the temperature of education vouchers. I hope he gets his toe burnt. (Smith, 1995)

\section{Educational Policies of ACT New Zealand (ACT)}

The year 1995 also saw the continued dissemination of the educational policies of ACT New Zealand, the political party closely associated with Sir Roger Douglas (ACT, 1995). These policies, with their strong emphasis on greater school choice, competition, deregulation, and the notion of vouchers, also link to the theme of this paper. In a 1996 press release, ACT's Education Spokeswoman asserted that the answer to most problems in the education system "lies in the simple fact that it is a state run monopoly" (The Dominion, 3 February 1996). Douglas's own views on education are laid out more fully in his book Unfinished Business (1993). Like many similar critics, he opens up with an attack on the existing public education system.

With the steady shrinking of the private education sector, it is now largely a State industry and, like other government institutions, it has developed the same characteristic-a massive bureaucracy and at the school level a standardised service for everyone. There is no attempt, except in the most limited way, to serve individual student needs. The intention has been to 
ensure everyone has equal access to school education. (Douglas,

1993, p. 8)

Douglas views Tomorrow's Schools as involving only a "Clayton's devolution of power", whereas "a significant part of the answer for improved educational success ... [and] ... central to what I propose lies in removing government as an intermediary between parents and students and educational institutions" (p. 90). Greater choice is central to Douglas's view, providing "flexibility, innovation and variety" (p. 93). He regards choice and diversity as always going to be the exception in a public education system. Choice, "imposes its own discipline" thereby "improving overall performance". These virtues are closely linked to those of competition. Schools would have to "lift their performance to survive". Good schools would prosper and expand; badly performing schools would shrink and die if they didn't change" (p. 94).

The Douglas plan would involve giving parents vouchers to enable them to "become consumers of educational services in an open market place", buying directly the education service they wanted at any registered public or private school. The same market approach would be applied to school management. Management of government-owned schools would initially be in the hands of a board, half of whose members would be appointed by government and half elected by parents. At the end of year two they would be formed into companies with boards appointed by the shareholders. Each school would set its own fees according to the services offered (p. 98). Amongst other anticipated outcomes: some teachers would seek to form partnerships in order to purchase schools and establish their own school "brands" ("along the lines that lawyers and accountants do, for example Chapman Tripp and Price Waterhouse") (p. 102). Overseas companies and entrepreneurs interested in education would start up businesses in New Zealand. Local businesses would, together with educators, establish their "own school or a chain of schools, or a university or chain of universities" (p. 103).

\section{The Centre For Independent Studies}

The Centre for Independent Studies (CIS) is another current advocate of greater privatisation in education (Correspondence and Brochure, 1995). Founded in 1976, it is Australian-based, but has a Wellington office. It aims to "preserve and enhance the individual freedoms, including the rights to life, liberty and property of Australians and New Zealanders" (p. 1). Other beliefs include "a free democratic society under limited government". It sees its work as "often at the forefront of public debate" and advocated "deregulation, privatisation and a free market long before they became fashionable".

The Centre's extensive publishing list includes authors like F. A. Hayek, Milton Friedman, Thomas Sowell, Roger Kerr of the Business Roundtable, and Edwin West, author of The Education Monopoly Problem (1989) and a prominent advocate of vouchers and strengthening private schools. Other activities include the invitation to New Zealand of overseas speakers to expand on ideas the Centre advocates. In 1993 it brought over Dr Byron Lieberman, an American critic of public school systems and author of books with titles like Public Education: An Autopsy (1993), Beyond Public Education (1986) and Privatisation and Educational Choice (1989). The close links between several of the organisations being discussed here was reflected in the fact that the Wellington public relations consultant who publicised Dr Lieberman's visit for the Centre has also been employed in the same capacity for the New Zealand Business Roundtable (Correspondence, G. Williamson, 17 November 1993). Dr Lieberman's recommendations for educational reform, outlined in a CIS Newssheet publicising his visit to New Zealand, include "the introduction of a system of vouchers, not only for general school education, but vouchers for separate subjects such as remedial instruction in basic skills. In high schools, subject vouchers might replace school vouchers entirely". Lieberman advocates that "starting no later than the senior high school level, parents should be prepared to pay at least ten per cent of the costs from their own pockets" and "for profit schools should not be disadvantaged in their ability to provide school services and should be able to compete on equal terms for students" (CIS Newssheet, November 1993).

In Beyond Public Education (1986) Lieberman presents his view that "private profit-making schools (hereinafter called 'entrepreneurial schools') will be the most effective way to achieve significant improvement in elementary and secondary education" (p. 3). This view is reinforced by his belief that "private enterprise must go beyond selling goods and services to public and non-profit elementary and secondary schools; school districts, schools, and programs within schools must be operated privately for profit on a much larger scale in order to bring about widespread educational achievement". In Privatisation and Educational Choice (1989), he pursues a similar theme: "the only ways to improve American education" are to: "(1) foster private schools that compete with public schools and among themselves and/or (2) foster for-profit competition among service providers within the public school 
system" (p. 4). He acknowledges that "both of these proposed ways to improve education require 'privatisation'. As used herein, the term denotes transferring activities conducted by public employees to the private sector" (p. 5).

Various ways in which school privatisation can be introduced are listed. including: (1) Contracting with independent contractors; (2) Vouchers; (3) Load shedding (described as "government shedding of support as well as operation of public services"); (4) Franchising; and (5) Subsidies to non-governmental suppliers. To Lieberman, if parents themselves pay for their children's education they are much more likely to insist on performance from both the "educational producers" and their own children. The student "who wastes time in school or cuts classes would be wasting family funds, not "the government's" (p. 290).

In his most recent book, Public Education: An Autopsy, referred to earlier and highlighted by the CIS in publicising his visit to New Zealand, Dr Lieberman's views appear to have remained remarkably consistent. Here is a sampling: "public education as we know it is a lost cause ... what has died is the rationale for public education" (p. 1); a market system is preferable to the existing system of public education ( $p$. 3); "schools for profit" are essential for a market system. "School boards should be able to contract out the management of the school district, just as hospitals are able to contract out hospital management" (pp. 276-277)

One question of interest is the extent to which any of the ideas advocated by overseas visitors like Dr Lieberman actually influence educational policy-making in New Zealand. It may only have been coincidental, but several months after his visit, Dr Lockwood Smith publicly affirmed his belief that secondary schools should be bulkfunded like universities and be able to charge students fees to take courses. In this instance he had in mind students taking tertiary courses while at school (Evening Post, 28 March, 1994).

\section{The Education Forum}

During 1995, the Education Forum was another organisation actively disseminating ideas advocating greater school privatisation. Based in Auckland, the Forum describes itself as "an association of individuals who have a common concern for the future direction of New Zealand education" (The Education Digest, April 1993). Forum members are said to come from the primary, secondary and tertiary education sectors, together with "leaders of industry and commerce". The chairman is John Taylor, principal of Kings College, a well-established Auckland private school. The Forum lists twelve principles which underlie its activities, including, "the acceptance of healthy competition for both individuals and the education sector"; "the emphasis on the value of parental choice in and the self management of education institutions";" the development of closer links between education institutions and industry" (The Education Digest, April 1993).

The Forum publication, The Education Digest includes articles by New Zealand and overseas authors on a wide range of topics. Most issues include several articles on the virtues of greater school privatisation. At the bottom of the list of contents of every issue the reader is informed that an asterisk alongside a particular paper denotes that it was "brought to the attention of The Education Digest through inclusion in News and Views published by the Hudson Institute". Three such articles were acknowledged in each of the April and August 1995 issues. The significance of this is that the Hudson Institute is well known as a conservative think-tank, which had close ties to Presidents Reagan and Bush, has former Vice-President Quayle on its board, and has promoted projects advocating greater school privatisation. The April 1995 issue contained an article by Gary S. Becker, a Fellow at the Hoover Institute (another conservative think-tank), entitled School Finance Reform: Don't Give up on Vouchers (1995). This advocated vouchers to assist all students to attend private schools if they choose. The August 1995 issue reproduced Perestroika and the Private Provider, by John Coons, an early advocate of educational vouchers, here arguing the benefits of private schooling, and an address by Roger Kerr of the Business Roundtable to the South Island Conference of Deputy and Assistant Principals. He argues that currently there are

some unnecessary restrictions on choice ... [including] the uneven terms of competition between government and nongovernment schools. Choice would be greatly expanded by levelling the playing field ... I believe the government's prime role in education should be to protect minors from parental failure by regulating the sector where necessary, and to finance education on behalf of the community, with parents and students being able to opt for public or private providers on even terms ...There is also an argument to be made that the government's financing role should be confined to ensuring access to education for those with insufficient means. (p. 106)

The November 1994 issue contained an article by Chester Finn, an Assistant Secretary of Education in the Reagan administration and a founder of the Edison Project, designed to provide models and promote 
wider development of privatised schooling in America. Finn asks, "Why is it necessary for public education to be administered by government agencies? Could it be administered perhaps better ... [if] it were privatised, partly privatised or contracted out" (p. 4).

The August 1993 issue featured an article on Christopher Whittle, described as a "media mogul" who made his fortune niche-marketing targeted consumers. In return for large scale supply of television equipment (\$50,000 worth of television sets, VCR's and satellite discs) and a daily 10-minute current affairs program to a school, Whittle requires students to watch two minutes of advertising each day. The author describes how Mr Whittle was now trying to bring about public reform of schools from the private sector. He is, in effect declaring war on public schools. This summer Mr Whittle announced plans to spend $\$ 2.5$ billion setting up, by 1996, a chain of 200 schools. If they proved successful, 800 would follow" (p. 12).

The purpose of all this, according to the author, is to equal or undercut the costs of public schooling; success will open the door for public money to follow children into private schools.

\section{The Independent Schools Council}

Another body which continued to promote keenly the interests of private school education in New Zealand during 1995 was the Independent Schools Council, representing a large number of private schools. A newsletter Focus On is widely distributed and introduces readers to policies the Council advocates. Approximately one half of the July 1995 issue, for example, was devoted to an extensive quote by Chester Finn, whom the Council brought to New Zealand as a guest speaker in 1995. A central theme of the Executive Director's advocacy role in the media and other forums is the need to increase government expenditure on private schools. The July 1993 issue of Focus On suggested that, "Almost everywhere they (independent schools) receive a significant amount of public funding" (p. 1). Various examples are reproduced from different countries, the purpose being to contrast the situation existing in them with what is claimed to be the comparatively low government contribution to private schools in New Zealand.

\section{Conclusion}

The organisations and individuals described in this paper share a common belief that the role of private schooling should be expanded. Most also believe this should be achieved by a significantly increased financial contribution by government directly to parents. It is argued that advocacy of increased private schooling comes from diverse sources, both from within New Zealand and abroad. Some sources of influence are quite well known, others much less so, certainly by members of the public. I am aware that some Maori have an interest in the possibilities of private provision as one way to develop, for example, the idea of tino rangatiratanga, While I have not discussed that aspect here, it is currently being examined (Personal communication, Graham Smith, 1996). I have also not discussed here the long-standing interest of the Treasury in the topic. Views about the degree to which private schooling should be increased and the best means of achieving that goal vary somewhat, but there are some consistent themes. The majority of advocates appear, at least in their public utterances, to favour what might be called the better balance argument. That is, they advocate measures designed to expand private education to provide more equal provision with public education, rather than the elimination of public education entirely. They do this on the grounds of, as they see it, a need for more choice, competition, efficiency, a more business-like approach to education, a user-pays philosophy and/or because of perceived limitations in the public school sector.

Giving parents vouchers with government funding so that they can "become consumers of educational services in an open market place" of both public and private schools features in the suggestions of many advocates, although taking a diversity of forms. And the idea of schools as profit-making enterprises also figures quite prominently.

What frequently struck me in undertaking this review was the unproblematic way in which many of the views asserted were presented, given the complexities of modern education systems. Assertions that education should be privatised and treated like any other commodity, for example, are seldom accompanied by analysis as to why this should be done, or adequate acknowledgment that schools are very different from a supermarket, a post-office or a railway station. Undue emphasis on a business orientation, which views the profit motive as a model for schools, seems inappropriate in the context of the many qualitative aspects of the work of schools, their importance in developing such qualities as a sense of civic responsibility and the preservation of a democratic ethos (to mention just two).

The political context will obviously continue to be important in relation to the theme of this paper, as it will be for many other education issues while the country prepares for its first election under a new mixed member proportional electoral system (MMP). Most of the opposition 
political parties, including Labour, The Alliance, New Zealand First and United, reacted negatively to further aid to private schools in general and the TIE scheme in particular. They favour the State remaining the main provider and funder, with more diversity and choice being encouraged within the state sector. The National government is currently a minority government and on current predictions it will have to establish alliances with other parties if it is to remain the government after the election.

My own view, in conclusion, is that instead of moving to the private sector, competitive market-model New Zealand needs universally excellent public schools committed to educational excellence, pluralism and equality of educational opportunity. We need this now as much if not more than we ever have in our history.

\section{References}

ACT New Zealand. (n.d.). Common sense for a change.

ACT New Zealand. (1996, February 3). Press Statement. The Dominion.

Brookes, W. T. (1995, April). Can educational choice save our schools? The Education Digest.

Becker G. S. (1995, April). School finance reform: Don't give up on vouchers. The Education Digest.

Centre for Independent Studies. (1993, November 17). Communication regarding seminar by Dr Lieberman.

Centre for Independent Studies. (1993). Brochure and Newsheet.

Clark, Helen (1995, August 14). Report in The Dominion.

Coons, J.E. (1995, April 11). Perestroika and the public provider. The Education Digest.

Douglas, R. (1993). Unfinished Business. Auckland: Random House.

Duncan, Helen (1995, September 18). Press Statement.

Finn, Chester (1995, August). What to do about education. The Schools Education Digest.

Independent Schools Council Newsletters.

Kerr, Jan (1995, September 19). Labour move denounced. The Dominion.

Kerr, Jan (1995, October 26). A choice of school for the poor. The Dominion.

Kerr, R. (1995, April 22). Address to South Island Conference of Deputy and Assistant Principals.

Lauder, Hugh et al. (1994). The creation of market competition for education in New Zealand. First report to the Minister of Education.

Lieberman, M. (1986). Beyond public education. New York: Praeger.
Lieberman, M. (1989). Privatization and educational choice. New York: St. Martin's Press.

Lieberman, M. (1993). Public education: An autopsy. Cambridge, Mass: Harvard University Press.

Noonan, Ros, (1995, August 8). Press statement.

Office of the Minister of Education. (n.d.). Papers on Targeted Individual Entitlement Scheme. To Chair of Cabinet Committee on Education, Training and Employment.

Office of the Minister of Education. (n.d.). Papers on TIE Scheme. To Families and School Administrators.

Office of the Minister of Education (1995, July 18). News Release.

Office of the Minister of Education. (1995, November 4). Speech notes for address to Vancouver Conference.

Office of the Minister of Finance. (1995). Budget and fiscal strategy report. Wellington.

Office of the Minister of Finance. (1995). Targeted Individual Entitlement Scheme. Wellington.

Sexton, Stuart (1990). New Zealand Schools. Wellington: New Zealand Business Roundtable.

Smith, Lockwood, Minister of Education. (1994, March 28). Evening Post. Smith, Nick (1995, August 10). Nelson Evening Mail.

Walberg, H.J., and Best, J.E. (1995, April). School choice: the essential reform. The Education Digest.

West, E.G. (1989). The education monopoly problem. CIS Occasional Papers 26.

\section{The author}

Dr John Barrington is Associate Professor in Education at Victoria University of Wellington. His research interests include educational administration and history. 